\title{
MIEJSCE PAMIĘCI \\ W PRAWIE HISZPAŃSKIM
}

Places of Memory in the Spanish Law

Anna Ławicka*

SUMMARY: Interpretation of the concept of of the Autonomous Community of Madrid. a place of remembrance in Spanish law of The indicated errors should be a warning and historical heritage protection is carried out forcing to reflection. inconsistently. This article attempts to present problems that arise in the qualification of KEYWORDS: law, sitio historico, place of given areas as places of remembrance and memory, Spain, protection of historical to discuss their essence using the example heritage, cultural property

Na ogół miejsce pamięci w kontekście ochrony dziedzictwa jest używane w dość wąskim rozumieniu. Hiszpania jako państwo niezwykle obfitujące w dziedzictwo kulturalne i historyczne, posiadająca rozbudowany system ochrony, oczywiście posługuje się konstrukcją miejsca pamięci. Jednakże należy wskazać, że i w tym przypadku nie dzieje się to bez problemów, przy czym stosowane rozumienie pojęcia jest czasem nadto szerokie, bądź w ogóle nielogiczne. Miejsce pamięci jest uważane za jedno z najbardziej "dziwnych" pojęć wprowadzanych przez ustawę z 1985 r. Hiszpanie mają problem z jego nieokreślonością, ponieważ może ono pomieścić dobra tak różne, jak elementy przyrody i całe krajobrazy.

Aby zrozumieć ochronę prawną przyznawaną miejscom pamięci w hiszpańskim systemie ochronyipłynącezniej konsekwencje, należy wyjaśnićjaksystem ten funkcjonuje. Najważniejszym aktem prawnym ogólnokrajowym $\mathrm{w}$ tej dziedzinie jest ustawa o hiszpańskim dziedzictwie historycznym 16/1985 z 25 czerwca 1985 r. (dalej ustawa 16/1985) ${ }^{1}$ zaakceptowana Dekretem Królewskim 111/1986 z 10 stycznia 1986 r. ${ }^{2}$, która zapewnia ochronę, poprawę i przekazywanie hiszpańskiego dziedzictwa kulturowego przyszłym pokoleniom. W art. pierwszym zawarta jest definicja dziedzictwa historycznego, które rozumie się jako zespól obiektów ruchomych inieruchomych o charakterze artystycznym, historycznym, paleontologicznym, archeologicznym, dokumentalnym, literackim, naukowym czy technicznym. Zgodnie $\mathrm{z}$ powyższą ustawą dziedzictwo historyczne Hiszpanii stanowią budynki, obiekty ruchome o różnym charakterze, a także: miejsca wykopalisk archeologicznych, ogrody, parki o wartości artystycznej, historycznej, antropologicznej. Najważniejsze elementy hiszpańskiego dziedzictwa powinny zostać poddane

\footnotetext{
* Anna Ławicka, University of Gdańsk https://orcid.org/0000-0002-6947-2554

1 Ley 16/1985, de 25 de junio, del Patrimonio Histórico Español, BOE núm. 155, de 29/06/1985.

2 Real Decreto 111/1986, de 10 de enero, de desarrollo parcial de la Ley 16/1985, de 25 de junio, del Patrimonio Histórico Español, «BOE» núm. 24, de 28 de enero de 1986, páginas 3815 a 3831.
} 
inwentaryzacji lub zadeklarowane jako dobra kultury w terminach przewidzianych omawianą ustawą. Kulturowe dziedzictwo jest jednym z priorytetów hiszpańskiej polityki. Pod swoją opieką Ministerstwo Edukacji, Kultury i Sportu posiada między innymi:

- Dziedzictwo Światowe (Patrimonio Mundial), czyli hiszpańskie obiekty wpisane na Listę Światowego Dziedzictwa UNESCO;

- Dziedzictwo Kulturowe Niematerialne (Patrimonio Cultural Inmaterial), czyli tradycje, zwyczaje, obrzędy i zjawiska, uznane za Niematerialne Dziedzictwo Ludzkości przez UNESCO;

- Dziedzictwo Kulturowe Podwodne (Patrimonio Culturl Subacuatico), czyli takie, które według definicji znajdowało się pod wodą przez minimum 100 lat;

- Dziedzictwo Europejskie (Patrimonio Europeo), jako część programu Unii Europejskiej;

- Chronione Dobra Kultury (Bienes culturales protegidos), czyli obiekty, które - w skali państwa lub jednej z 17 wspólnot autonomicznych - zostały uznane za wyjątkowo ważne i ustanowiono dla nich szczególną ochronę.

Generalna Dyrekcja Sztuk Pięknych, Dóbr Kultury, Archiwów i Bibliotek (Dirección General de Bellas Artes y Bienes Culturales y de Archivos y Bibliotecas) za pośrednictwem Urzędu Ochrony Dziedzictwa Historycznego (Subdirección General de Protección del Patrimonio Histórico), jest odpowiedzialna za utrzymanie i aktualizację Generalnego Rejestru Dóbr Kultury (Registro General de Bienes de Interes Cultural) oraz Generalnego Inwentarza Dóbr Ruchomych (Inventario General de Bienes Muebles), które zawierają informacje na temat dóbr dla których wspólnoty autonomiczne lub rząd hiszpański postanowiły stworzyć jakąś ochronę. Ustawa dzieli dobra kultury na ruchome i nieruchome.

Dobra kultury ruchome zgodnie z art. 335 kodeksu cywilnego ${ }^{3}$ mogą zostać przywłaszczone i nie są uważane za rzeczy nieruchome. To dobra, które mogą być transportowane z jednego punktu do drugiego, bez szkody dla obiektu stałego, do którego są dołączone. Przedmioty z tej kategorii mogą zostać albo uznane za dobra kultury albo włączone do Generalnego Inwentarza Dóbr Ruchomych.

Nieruchome dobra kultury zostały zdefiniowane w art. 334 kodeksu cywilnego i może je stanowić element, który jest uważany za nierozerwalnie związany z budynkami, a który stanowi lub stanowił część z nich lub ich otoczenia, który nawet jeśli go oddzielić, tworzy doskonałą całość, którą można łatwo zastosować do innych budynków lub innych zastosowań niż pierwotnego użytku. Ustawa 16/1985 wprowadza podział nieruchomych dóbr kultury na następujące kategorie, które zastąpiły w 1985 r. pojedynczą kategorię zabytku narodowego (monumento nacional):

- zabytek (monumento);

- ogród historyczny (jardin historico);

- zespół historyczny (conjunto historico);

- miejsce pamięci (sitio historico);

3 Real Decreto de 24 de julio de 1889 por el que se publica el Código Civil, BOE núm. 206, de 25/07/1889. 


\section{Miejsca pamięci w prawie hiszpańskim}

- obszar archeologiczny (zona arqueologica).

Hiszpańskie dobra kultury są regulowane przez przepisy szczególne, zawarte przede wszystkim we wspomnianej ustawie 16/1985. Przepisy te zawierają ogólny schemat i specjalne systemy oparte na charakterystyce obiektu chronionego. Ogólny schemat obejmuje trzy poziomy ochrony w oparciu o unikalne znaczenie dóbr. Uszeregowane od najmniejszej do największej ochrony, przedstawiają się następująco:

- Hiszpańskie Dziedzictwo Historyczne;

- Generalny Inwentarz Dóbr Ruchomych;

- Generalny Rejestr Dóbr Kultury.

\section{Hiszpańskie Dziedzictwo Historyczne}

Jest to minimalny poziom ochrony dóbr kultury. Hiszpańskie dziedzictwo historyczne obejmuje wszystkie nieruchomości i ruchomości o wartości artystycznej, historycznej, paleontologicznej, archeologicznej, etnograficznej, naukowej lub technicznej. Obejmuje również dziedzictwo dokumentalne i bibliograficzne, obszary archeologiczne, obszary przyrodnicze, ogrody i parki mające wartość artystyczną, historyczną lub antropologiczną (ustawa 16/1985, art. 1).

\section{Generalny Inwentarz Dóbr Ruchomych}

Wyższym poziomem ochrony od kategorii Hiszpańskiego Dziedzictwa Historycznego zostały objęte dobra ujęte w Generalnym Inwentarzu Dóbr Ruchomych (Inventario General de Bienes Muebles), które posiadają niezwykłe historyczne, archeologiczne, naukowe, artystyczne, techniczne lub kulturalne wartości i nie zostały uznane za dobra kultury (Bienes de Interés Cultural). Organizacja i funkcjonowanie tej inwentaryzacji została określona $\mathrm{w}$ przepisach prawa (ustawa 16/1985, art. 26).

\section{Dobra Kultury}

Maksymalnym poziomem ochrony objęto nieruchomości i dobra ruchome uznane za Dobra Kultury. Dobra te zewidencjonowane są w Generalnym Rejestrze Dóbr Kultury (Registro General de Bienes de Interés Cultural). Do tejże kategorii należą miejsca pamięci.

Po pierwsze, Dobra Kultury ustanowione przez prawo jako takie, to budynki wyznaczone do archiwów, bibliotek i muzeów państwowych, jak również dobra ruchome w nich przechowywane. Obejmują one także jaskinie, groty, schrony itp., które zawierają malarstwo jaskiniowe, zamki, symbole, cruz de término (krzyże graniczne) i tym podobne elementy.

Po drugie, Dobra Kultury ustanowione indywidualnie Dekretem Królewskim wymagają uprzedniego otwarcia procedury administracyjnej. Na szczeblu ogólnokrajowym, muszą uzyskać pozytywną opinię od jednej z następujących instytucji doradczych: Zarządu Klasyfikacji, 
Wyceny i Eksportu Dóbr Hiszpańskiego Historycznego Dziedzictwa (Junta de Calificación, Valoración y Exportación de Bienes del Patrimonio Histórico Español), Królewskich Akademii (Reales Academias), hiszpańskich uniwersytetów (lUniversidades españolas), Wyższej Rady Badań Naukowych (Consejo Superior de Investigaciones Científicas) lub wyższych Rad (Juntas Superiores). W przypadku dóbr dotyczących wspólnot autonomicznych, opinia zostaje wydana przez instytucje uznane przez daną autonomię.

\section{Definiowanie i interpretacja miejsca pamięci}

Definicja miejsca pamięci znajduje się w art. 15.4 ustawy o hiszpańskim dziedzictwie historycznym i zgodnie $\mathrm{z}$ jego brzmieniem stanowi miejsce lub pejzaż naturalny związany z wydarzeniami lub wspomnieniami z przeszłości, z popularnymi tradycjami, twórczością kulturalną lub naturalną i dziełami człowieka, które reprezentują wartość historyczną, etnologiczną, paleontologiczną lub antropologiczną. Miejsce pamięci jest nieruchomością, objętą najwyższym poziomem ochrony przyznawanej elementom Hiszpańskiego Dziedzictwa Historycznego, wpisaną do Generalnego Rejestru Dóbr Kultury.

Istnienie warunków posiadania wartości etnograficznej i antropologicznej pozwala na pośrednią ochronę dziedzictwa niematerialnego, przyznając mu prawną ochronę związanego z nim podłoża materialnego. Miejsce pamięci pozwala chronić pośrednio tylko bardzo ograniczony ułamek elementów dziedzictwa niematerialnego jak np. popularne tradycje związane z naturalnym miejscem ${ }^{4}$. Wydaje się, ze krajobraz przyrodniczy utworzony przez siły kreujące natury, może być częścią tego dziedzictwa. Oczywiście, o ile ma on wartość historyczną, etnologiczną, paleontologiczną lub antropologiczną. Jednakże z drugiej strony, odwołujemy się do naturalnych miejsc, ogrodów i parków, które mają jakiś związek z działalnością człowieka, ale nie ma mowy tutaj o dziedzictwie naturalnym, które będzie przedmiotem innego prawa ${ }^{5}$.

Jak już wspomniano powyżej prawo rozróżnia, w przypadku nieruchomych Dóbr Kultury: zabytki, ogrody, zespoły historyczne, miejsca pamięci, a także obszary archeologiczne. W bazie danych nieruchomości Ministerstwa Edukacji, Kultury i Sportu zabytki stanowią liczbę 13 795, ogrody historyczne 112, zespoły historyczne 1048 , natomiast obszary archeologiczne 982. Miejsc pamięci jest zarejestrowanych 286, przy czym nie mniej niż 65 odpowiada śladom i pozostałościom po jurajskim. Stanowią one zatem niewielki procent objętych ochroną nieruchomości. Co konkretnie znajdziemy w rejestrze pod pojęciem miejsca pamięci? Będzie to między innymi silbo gomero, język gwizdów, używany przez mieszkańców wyspy Gomera należącej do archipelagu Wysp Kanaryjskich, w celu porozumiewania się na duże odległości. (zarejestrowany jako nieruchomość!). Kolejną niespodzianką może okazać się Fiesta de la Rama se las Marias na Gran Canarii, która jest aktem świątecznej i religijnej natury. Istnieje kilka miejsc pamięci, które korespondują z naturalnymi miejscami słynącymi pięknem jak np. dolina

4 L.P. Martinez, La tutela legal del patrimonio cultural inmaterial en Espana: Valoraacion y perspectivas, Revista de la Facultad de Ciencias Sociales y Jurídicas de Elche, Volumen I, Número 7, Junio de 2011, s.127.

5 F.H. Hernandez, La Conservación Integral Del Patrimonio, Complutunt Extra, 6(U), 1996, s.254. 
Benasque, dolina Barranco de Los Molinos, północno-zachodnie wybrzeże Majorki. Nie jest w tym przypadku jasne, czy owe dziedzictwo przyrodnicze spełnia kryteria reprezentowania wartości historycznej, etnologicznej, paleontologicznej lub antropologicznej, chociaż dobrze wiadomo, że hiszpańskie ustawodawstwo zawsze uważa piękno za charakterystyczny i definiujący element krajobrazu. Ustawa z 13 maja 1933 r. o Obronie, Konserwacji i Nabywaniu Narodowego Artystycznego Dziedzictwa Historycznego wspominała o potrzebie opieki i ochrony malowniczych pejzaży (los parajes pintoresco), jednakże obecnie konstrukcja ta nie istnieje w obowiązującym prawie z 1985 r. Ich "konwersja" do miejsc pamięci została dokonana $\mathrm{z}$ wieloma trudnościami w wielu przypadkach. Nawet niektóre lepiej pasowałyby do przepisów sektorowych dotyczących ochrony dziedzictwa przyrodniczego.

\begin{tabular}{|c|c|c|c|c|c|c|}
\hline $\begin{array}{c}\text { Wspólnota } \\
\text { Autonomiczna }\end{array}$ & Zabytki & $\begin{array}{c}\text { Ogrody } \\
\text { historyczne }\end{array}$ & $\begin{array}{c}\text { Zespoły } \\
\text { historyczne }\end{array}$ & $\begin{array}{c}\text { Miejsca } \\
\text { pamięci }\end{array}$ & $\begin{array}{c}\text { Obszary } \\
\text { archeologi- } \\
\text { czne }\end{array}$ & $\%$ \\
\hline Andaluzja & 2578 & 18 & 170 & 21 & 170 & 18,40 \\
\hline Aragonia & 643 & 0 & 61 & 22 & 52 & 4,84 \\
\hline Asturia & 295 & 0 & 28 & 2 & 6 & 2,06 \\
\hline Baleary & 2849 & 10 & 44 & 18 & 105 & 18,83 \\
\hline $\begin{array}{c}\text { Wyspy } \\
\text { Kanaryjskie }\end{array}$ & 375 & 14 & 65 & 59 & 141 & 4,07 \\
\hline Kantabria & 238 & 4 & 29 & 4 & 44 & 1,98 \\
\hline Kastylia i Leon & 979 & 6 & 133 & 18 & 162 & 8,07 \\
\hline Kastylia-La & 676 & 0 & 39 & 7 & 47 & 4,78 \\
\hline Mancha & 2039 & 7 & 71 & 33 & 90 & 13,94 \\
\hline Katalonia & 29 & 0 & 73 & 0 & 2 & 0,65 \\
\hline Cueta i Melilla & 954 & 6 & 32 & 17 & 54 & 6,61 \\
\hline Walencja & 188 & 1 & 41 & 8 & 14 & 1,57 \\
\hline Estremadura & 589 & 8 & 49 & 15 & 5 & 4,14 \\
\hline Galicja & 107 & 1 & 8 & 41 & 1 & 0,98 \\
\hline La Rioja & 374 & 25 & 21 & 7 & 42 & 2,92 \\
\hline Madryt & 464 & 0 & 11 & 9 & 28 & 3,19 \\
\hline Murcja & 149 & 0 & 18 & 5 & 16 & 1,17 \\
\hline Nawarra & 263 & 0 & 16 & 0 & 3 & 1,75 \\
\hline Kraj Basków & $\mathbf{1 3 7 9 5}$ & $\mathbf{1 0 0}$ & $\mathbf{9 0 9}$ & $\mathbf{2 8 6}$ & $\mathbf{9 8 2}$ & $\mathbf{1 0 0 , 0 0}$ \\
\hline Suma: & & & & & & \\
\hline
\end{tabular}

Tabela 1. Nieruchome dobra kultury w poszczególnych wspólnotach autonomicznych (2018) Opracowanie własne na podstawie danych z bazy Ministerstwa Edukacji, Kultury i Sportu. 
Dr José Fariña Tojo omawiając miejsca pamięci posłużył się przykładem Wspólnoty Autonomicznej Madrytu jako kwintesencji problematyczności kwalifikowania miejsc pamięci w Hiszpanii ${ }^{6}$. W bazie danych Ministerstwa Kultury pojawia się w tej wspólnocie tylko siedem zarejestrowanych miejsc pamięci: pole bitwy pod Samosierrą (Campo de Batalla de Somosierra), dwa malownicze pejzaże: jedno wokół Pałacu Królewskiego (Paraje Pintoresco rodea al Palacio), drugie w postaci sosnowego lasu (Paraje Pintoresco El Pinar de Abantos), kamień Roca del Consistorio, kaplicę Capilla de la cuadra de San Isidro, park El Capricho Alameda de Osuna, i Niektóre Obszary Królewskiego Miejsca San Lorenzo del Escorial (Determinadas Zonas del Real Sitio de San Lorenzo de El Escorial).

Pole bitwy jest najbardziej oczywistym zakwalifikowaniem miejsca pamięci ze wszystkich. Można by nawet pokusić się o stwierdzenie, że miejsce gdzie odbyła się ważna bitwa, stanowi paradygmat miejsca pamięci. W przypadku pola bitwy pod Somosierrą, 400 hektarowy obszar zarejestrowano 19 lutego 2002 roku. W tym miejscu 30 listopada 1808 roku wojska hiszpańskie zostały pokonane przez armię Napoleona. Ośmiominutowa szarża polskiego oddziału zakończyła się pełnym sukcesem i przyczyniła się do otwarcia wojskom napoleońskim drogi na Madryt ${ }^{7}$. To historyczne miejsce jest tylko topograficzną scenerią, jedyne co się tam znajduje to ślady fortu i pustelni la Soledad. Jednakże uznanie pola bitwy za miejsce pamięci, było nazywane przez hiszpańską opinię publiczną pionierskim, ponieważ w tym kraju pola bitew nie były brane pod uwagę jako elementy dziedzictwa historycznego, przez wzgląd na wykraczanie poza materialną kreację. Dodatkowo wskazywano, że zachowane na tym terenie znaleziska archeologiczne są śladowe. W dużej mierze miejsce to uznano za Dobro Kultury w odpowiedzi na prośby ambasadorów z Polski i Francji. Bitwa pod Somosierrą nie cieszy się popularnością w Hiszpanii, jest to wydarzenie historyczne, które zostało skutecznie zdegradowane w pamięci ludności. Jedynym wyjątkiem było małe muzeum parafialne, które prowadzi ksiądz José Medina Pintado i dwie pamiątkowe tablice w pustelni poświęconej poległym $\mathrm{z}$ obu stron ${ }^{8}$. Zatem mamy tutaj do czynienia $\mathrm{z}$ ochroną prawną pamięci o wydarzeniu, o którym sami Hiszpanie chcą wręcz zapomnieć.

Kolejne miejsce pamięci to kamień (Roca del Consistorio lub Piedra del Concejo). W 1630r. król Felipe IV przyznał Collado Villalbie przywilej Villazgo na prośbę księżnej Infantado, za cenę 300 dukatów na wsparcie armii włoskich. Prymitywna rada miejska spotykała się na dźwięk dzwonka, na szczycie skały od strony Placu Ratuszowego. Kamień byłjednym z kroków podjętych przez burmistrza Sanz w 1724 r. dla poprawy komfortu rady ${ }^{9}$. Niewątpliwie jest to historyczne miejsce dla społeczności Madrytu. 22 października 1991 r. rozpoczęto proces uznania go za miejsce pamięci, który nie został rozstrzygnięty do tej pory i nie ma wydanej odpowiedniej deklaracji. Tam gdzie społeczności zależy na pielęgnowaniu i ochronie pozostałości i symbolu pewnych wydarzeń, biurokracja stanęła w miejscu. Być może dla inwestorów nieruchomości

6 www.elblogdefarina.blogspot.com/2014/09/sitios-historicos-enredar-con-el.html odczyt z dnia 14.02.2018r.

7 www.muzhp.pl/pl/e/1807/szarza-polskich-ulanow-pod-somosierra odczyt z dnia 14.02.2018r.

8 www.elpais.com/diario/2002/03/17/madrid/1016367867_850215.html odczyt z dnia 14.02.2018r.

9 www.ayto-colladovillalba.org/es/tu-municipio/historia/edad-moderna/ odczyt z dnia 14.02.2018r. 


\section{Miejsca pamięci w prawie hiszpańskim

stan ten jest pożądany.

Następnie mamy dwa malownicze pejzaże zadeklarowane przed wejściem w życie ustawy z 1985 r. Pierwszy to otoczenie pałacu Boadilla del Monte zadeklarowane dnia 20 lipca 1974r., drugie to sosnowy las Abantos w El Escorial z 16 listopada 1961 r. Objęcie malowniczego pejzażu otoczenia pałacu ochroną przyznawaną miejscu pamięci jest co najmniej dyskusyjne. Kompleks składa się z ogrodu, sadu i parku, który służy jako łącznik pomiędzy architekturą pałacową a wiejską. Trudno jest zakwalifikować go do którejkolwiek kategorii nieruchomych Dóbr Kultury, ponieważ w rzeczywistości jest elementem mieszanym. Jednak, czy nie byłoby lepiej uznać go za ogród historyczny lub skorzystać z form ochrony prawnej przyznawanej przez ustawę o różnorodności biologicznej i środowiska naturalnego z 2007 roku $^{10}$ ?

Las sosnowy Pinara de Abantosa w El Escorial występuje jako malownicze tło klasztoru, nieodzowny i bezcenny dla zrozumienia kompleksu Herrerii krajobraz. Tak jak w poprzednim przypadku fakt, iż stał się miejscem pamięci jest co najmniej zastanawiający, ponieważ jest to mniej lub bardziej naturalny las sosnowy, w którym nic znaczącego się nie wydarzyło, a którego dopasowanie do ustawy z 2007 r. o dziedzictwie przyrodniczym i bioróżnorodności wydaje się dużo bardziej logiczne. Oba przypadki, podobnie jak wiele innych dotyczących malowniczych pejzaży zadeklarowanych przed ustawą z 1985 r., ujawniają poważne niedociągnięcia tej ustawy w stosunku do krajobrazu, czy to miejskiego, czy naturalnego. To samo dzieje się z innym miejscem pamięci społeczności Madrytu, wpisanym do bazy pod nazwą "Niektóre Obszary Królewskiego Miejsca San Lorenzo del Escorial" zadeklarowanym w 1971 r. Już sama jego nazwa wskazuje na trudności przystosowywania rzeczywistości do niektórych figur prawnych.

Domniemany chlew San Isidro Labrador (obecnie kaplica), zadeklarowany jako miejsce pamięci w 2000 r., znajduje się w piwnicy domu z 1859 r., gdzie wydaje się, że święty Izydor Oracz, patron Madrytu, przechowywał materiały rolnicze i część żywego inwentarza. Przypadek ten po pierwsze ilustruje, że to co podlega ochronie, nie jest architekturą a lokalizacją. Po drugie, miejsce pamięci może znajdować się tak w mieście, jak i w szczerym polu (bitwa pod Somosierrą). Istotne jest to, że w tym miejscu mogło wydarzyć się prawie wszystko, chociaż nie ma żadnego historycznego wydarzenia, które by to potwierdziło. Dlatego, mity, wierzenia lub przesądy, mogą tutaj również zostać przyjęte jako miejsca pamięci.

Ostatnim madryckim miejscem pamięci jest Park Capricho Alameda de Osuna, zamówiony przez Księżną Osuny w 1787 r. Pomimo, że jest wzorem ogrodu historycznego, który nawet na oficjalnej stronie Rady Miejskiej Madrytu jest tak określony ${ }^{11}$, to w bazie danych Ministerstwa Kultury figuruje jako miejsce pamięci $z$ datą wszczęcia procedury (nie ma deklaracji) dnia 24 października $1979 \mathrm{r}$.

Jak komentuje dr José Fariña, prezentowane przypadki kształtują miejsca pamięci jako

10 Ley 42/2007, de 13 de diciembre, del Patrimonio Natural y de la Biodiversidad, BOE núm. 299, de 14/12/2007.

11 Zob.www.madrid.es/portales/munimadrid/es/Inicio/El-Ayuntamiento/Medio-ambiente/Parques-yjardines/Patrimonio-Verde/Parques-en-Madrid/Jardin-Historico-El-Capricho-de-la-Alameda-Osuna?vgnext $\mathrm{fmt}=$ default\&vgnextoid=9db6fb010e99e210VgnVCM1000000b205a0aRCRD\&vgnextchannel=38bb1914e7d 4e210VgnVCM1000000b205a0aRCRD 


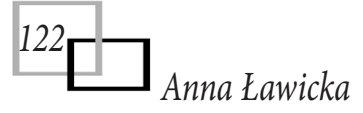

"rzadki gatunek" hiszpańskiego dziedzictwa kulturowego, zbiór wielu rzeczy, do których nie bardzo wiadomo jak podejść czy to koncepcyjnie, czy legislacyjnie. Gdyby zastąpiła je inna konstrukcja zbudowana $\mathrm{z}$ wykorzystaniem zdrowego rozsądku, prawie nikt nie opłakiwałby jego zniknięcia ${ }^{12}$. Jak wykazano, interpretacja miejsca pamięci w Hiszpanii stanowi nie lada problem i wyzwanie. Szczególnie kłopotliwa wydaje się tutaj być kwestia zarówno ochrony obszarów przyrodniczych (czy elementy, które je tworzą, są mniej lub bardziej antropologiczne), jak i dziedzictwa niematerialnego. 


\section{Bibliografia}

\section{Akty prawne} de 1985.

1. Ley 16/1985, de 25 de junio, de Patrimono Histórico Español, BOE 155 de 26 de junio

2. Real Decreto 111/1986, de 10 de enero, de desarrollo parcial de la Ley 16/1985, de 25 de junio, del Patrimonio Histórico Español, BOE núm. 24, de 28 de enero de 1986, páginas 3815 a 3831.

3. Real Decreto de 24 de julio de 1889 por el que se publica el Código Civil, BOE núm. 206, de 25/07/1889.

4. Ley $42 / 2007$, de 13 de diciembre, del Patrimonio Natural y de la Biodiversidad, BOE núm. 299, de 14/12/2007.

\section{Literatura}

1. L.P. Martinez, La tutela legal del patrimonio cultural inmaterial en Espana: Valoraacion y perspectivas, Revista de la Facultad de Ciencias Sociales y Jurídicas de Elche Volumen I Número 7 - Junio de 2011, s.127.

2. F.H. Hernandez, La Conservación Integral Del Patrimonio, Complutunt Extra, 6(U), 1996, s.254.

\section{Strony internetowe}

1. www.elblogdefarina.blogspot.com/2014/09/sitios-historicos-enredar-con-el.html

2. www.muzhp.pl/pl/e/1807/szarza-polskich-ulanow-pod-somosierra

3. www.elpais.com/diario/2002/03/17/madrid/1016367867_850215.html

4. www.ayto-colladovillalba.org/es/tu-municipio/historia/edad-moderna/ 